\title{
Electron microscope study of a case of Australia antigen-positive chronic hepatitis ${ }^{1}$
}

\author{
JUNE D. ALMEIDA², P. GIOANNINI, G. SCALISE, AND C. V. HARRISON
}

From the Royal Postgraduate Medical School, London, and the Pathology Department, University of Sassari, Italy

SYNOPSIS The laboratory findings in a case of Australia antigen ( $\mathrm{Au}-\mathrm{Ag}$ ) positive chronic hepatitis in a 4-year-old boy are given. Studies by the electron microscope technique of thin sectioning revealed the presence of $200 \AA$ particles in the nuclei of hepatocytes. These particles are identical to those described previously in occasional specimens of Au-Ag-positive liver tissue. However, the pattern found here differs from previous descriptions inasmuch as no heavily infected nuclei could be found but almost all nuclei could be shown to contain extremely small numbers of these particles. The significance of this finding is discussed and the danger that it would be easy to obtain false negatives in similar tissue pointed out.

It is now well established that the Australia antigen ( $\mathrm{Au}-\mathrm{Ag})$ is an acceptable laboratory marker for the presence of serum hepatitis virus. The electron microscope technique of negative staining has shown that the Au-Ag exists in three morphological forms, namely, $200 \AA$ diameter rods and spheres, and a more complex double-shelled particle of $420 \AA$ diameter known as the Dane particle (Dane, Cameron, and Briggs, 1970). More recently it has been shown that the Dane particle consists of two antigenically distinct components (Almeida, Rubenstein, and Stott, 1971): first, an outer envelope having antigens related to the smaller $200 \AA$ forms of the $\mathrm{Au}-\mathrm{Ag}$ and, second, an inner core that bears no antigenic relationship to these forms. Many attempts have been made to correlate these negatively stained forms of the $\mathrm{Au}-\mathrm{Ag}$ with the presence of structures in thinly sectioned livers from Au-Ag-positive cases. In 1970 Nowoslawski, Brzosko, Madaliński, and Krawczyński, showed $200 \AA$ diameter virus-like particles in the nuclei of hepatocytes from cases with lymphoproliferative disorders who were positive for the Au-Ag but who did not show clinical evidence of hepatic involvement. This finding has teen confirmed by several other workers (Nelson, Barker, and

'Since preparing this manuscript an article by Dunn et al has come to our attention. Findings similar to those described here are given although the interpretation of these facts differs.

Dunn, A. E. G., Peters, R. L., Schweitzer, I. L., and Spears, R. L. (1972). Arch Path, 94, 258-264.

${ }^{2}$ Present address: Wellcome Research Laboratories, Langley Court, Beckenham, Kent.

Received for publication 13 December 1972.
Danovitch, 1970; Caramia, De Bac, and Ricci, 1972; Scotto, Homberg, and Caroli, 1972) most of whom could find the intranuclear particles in the hepatocytes of asymptomatic carriers of the $\mathrm{Au}-\mathrm{Ag}$, but there are only occasional instances of these particles being seen in patients with active liver involvement, either acute or chronic. Huang (1971), in a study of liver biopsy material from antigenpositive carriers, has been able to show both $200 \AA$ intranuclear particles and also cytoplasmic particles some of which display a double-shelled structure and would seem to correspond to the Dane particles found in negatively stained preparations.

It is difficult to interpret the findings that such intranuclear particles can be found with relative ease in the hepatocytes of asymptomatic Au-Ag carriers but are found only occasionally and with difficulty in cases having active liver involvement.

Recently we have been able to study the case of a child with chronic hepatitis which may throw some light on this situation.

\section{Case History}

The patient is a Sardinian boy (S.G.) aged 4 years (born 9 April 1967), showing normal development. On 3 March 1971, he was admitted to a paediatric department suffering from jaundice and anorexia. The findings at that time were: liver $2 \mathrm{~cm}$ under rib edge; GOT $100 \mathrm{U}$ (normal value $45 \mathrm{U}$ ); GPT $290 \mathrm{U}$ (normal value $35 \mathrm{U}$ ); McLagan test 6.5 UML; 
bilirubin $1.6 \mathrm{mg} \%$. Liver biopsy and Au-Ag assay were not performed.

The child was discharged on 17 March 1971 (GOT $19 \mathrm{U}$; GPT $16 \mathrm{U}$ ) with a diagnosis of 'virus hepatitis'. Immediately after this, on 20 March 1971, he developed typical measles. After recovery from this disease his GOT and GPT were normal and the child remained well until August 1971 when he started to complain of anorexia, asthemia, and arthralgias. Tests undertaken at this time showed his serum enzyme levels to be as follows:

\begin{tabular}{lllll}
\hline 20 August 1971 & GOT & $142 \mathrm{U}$ & GPT & $133 \mathrm{U}$ \\
10 October 1971 & GOT & $475 \mathrm{U}$ & GPT & $350 \mathrm{U}$ \\
16 November 1971 & GOT & $380 \mathrm{U}$ & GPT & $280 \mathrm{U}$ \\
\hline
\end{tabular}

On 17 November 1971 the child was admitted to the Infectious Diseases Department of Sassari University. He was well nourished and the clinical findings were as follows: liver $1.5 \mathrm{~cm}$ under the rib edge and of firm consistency; spleen $0.5 \mathrm{~cm}$ under the left rib edge; no jaundice.

Biochemical tests at this time showed: GOT 335; GTP $305 \mathrm{U}$; bilirubin $0.5 \mathrm{mg} \%$; Maclagan test 5.0 UML; Serum protein $7.40 \mathrm{~g} \%$ (albumin $54.9 \%$, globulin $45.1 \%$, the globulin fraction broken further into $a_{1} 5.5 \%, a_{2} 9.9 \%, B 11.7 \%$, and V $18.0 \%$.

The ESP. (Westergren) was $16 \mathrm{~mm}$ in one hour.

Serum cholesterol was $164.0 \mathrm{mg} \%$, and urine analysis normal.

The Boyden test and faeces tests for parasitic diseases were negative.

The Au-Ag test carried out by the Ochterlony method of double diffusion in agar gel was strongly positive.

Antithyroid antibody was ++-- , anti-smooth muscle antibody ++-- , anti-kidney antibody ++- , IgG $10 \mathrm{mg} / \mathrm{ml}$ (normal 12.33 \pm 2.26 $\mathrm{mg} / \mathrm{ml}$ ), IgM $1.08 \mathrm{mg} / \mathrm{ml}$ (normal $1 \cdot 19 \pm 0.72 \mathrm{mg} / \mathrm{ml}$ ), IgA (Hyland radial-immunodiffusion test) 2.65 $\mathrm{mg} / \mathrm{ml}$ (normal $2.92 \pm 0.83 \mathrm{mg} / \mathrm{ml}$ ).

On 22 December 1971 (GOT 235; GPT 210 U) a surgical liver biopsy was performed. The liver was large, red, and firm. On 28 December 1971 the child was discharged with a prescription for betamethasone (Bentelan) $0.5 \mathrm{mg}$ pd. He was well and his serum transaminases gradually decreased.

On 2 February 1972 GOT was 95 U, GPT 130 U, serum bilirubin $0.5 \mathrm{mg} \%$. On 5 May 1972, when his serum enzymes were within normal limits (GOT 90 U; GPT $66 \mathrm{U}$ ), betamethasone was withdrawn and the child began to complain again of anorexia, postprandial vomiting, and loss of weight. The liver was unchanged.

On 5 June liver enzymes were considerably raisedGOT $290 \mathrm{U}$ and GPT $235 \mathrm{U}$.
The liver was enlarged but there was no jaundice. Immunosuppressive therapy was established againo in July with azathioprine $50 \mathrm{mg}$ pd and the child appears well although serum enzyme levels are stillos raised.

\section{Materials and Methods}

\section{LIVER BIOPSY}

A piece of tissue approximately one $1 \mathrm{ccm}$ was divided and prepared for both light and electron microscope. sectioning. The material for light microscopy was $\vec{\omega}$ fixed in absolute alcohol and paraffin sections wereo stained by haematoxylin and eosin silver reticulin, Best's method for glycogen, Perl's method for iron, N and methyl green pyronin for plasma cells. Tissue for $\mathrm{i}^{\circ}$ electron microscopy was fixed initially in bufferedgluteraldehyde, postfixed in osmium tetroxide, and $\vec{\omega}$ eventually embedded in epoxy resin.

\section{Results}

\section{LIGHT MICROSCOPY}

The section measured approximately $8 \times 8 \mathrm{~mm}$. Glisson's capsule was not thickened. Portal tracts $\overrightarrow{0}$ appeared enlarged to a maximum diameter of $500 \mathrm{\omega}$ microns and had irregular edges (fig. 1). Narrowi strands of fibre connected some portal tracts axid occasional narrower strands joined portal tracts central veins, but there was no nodular regeneration. In most of the biopsy the liver columns were of normal width, but in a few areas near fibrosed portal $\stackrel{\varrho}{\rightarrow}$ tracts they were widened and slightly irregular, buto을 rosettes were not seen. The portal tracts contained lymphocytes, usually in a localized cluster, and in one case in a definite follicle (fig. 2). Plasma cells were extremely scanty. There were increased numbers? of bile ducts in the portal tracts and in some places:these were surrounded by lymphocytes and were disintegrating (fig. 3). Small groups of liver cells, $\varrho$ loaded with glycogen, were isolated within the $₹$ enlarged portal tracts (fig. 4). Liver cells appeared응 healthy and in particular those near the portal tract $>$ were free from degenerative changes. Bile retention was not seen and there was no iron demonstrable.

These appearances are suggestive of either primary $\stackrel{\circ}{\circ}$ biliary cirrhosis or chronic aggressive hepatitis. The ${ }^{N}$ former is not compatible with the clinical findings, N and chronic aggressive hepatitis remains the likelyo diagnosis in spite of the apparent normality of the hepatocytes and virtual absence of plasma cells.

ELECTRON MICROSCOPY

Several sections from five different tissue blocks wereo examined in the electron microscope. In every case $\overrightarrow{\mathbb{Q}}$ normal liver architecture could be distinguished and $\overrightarrow{0}$ 


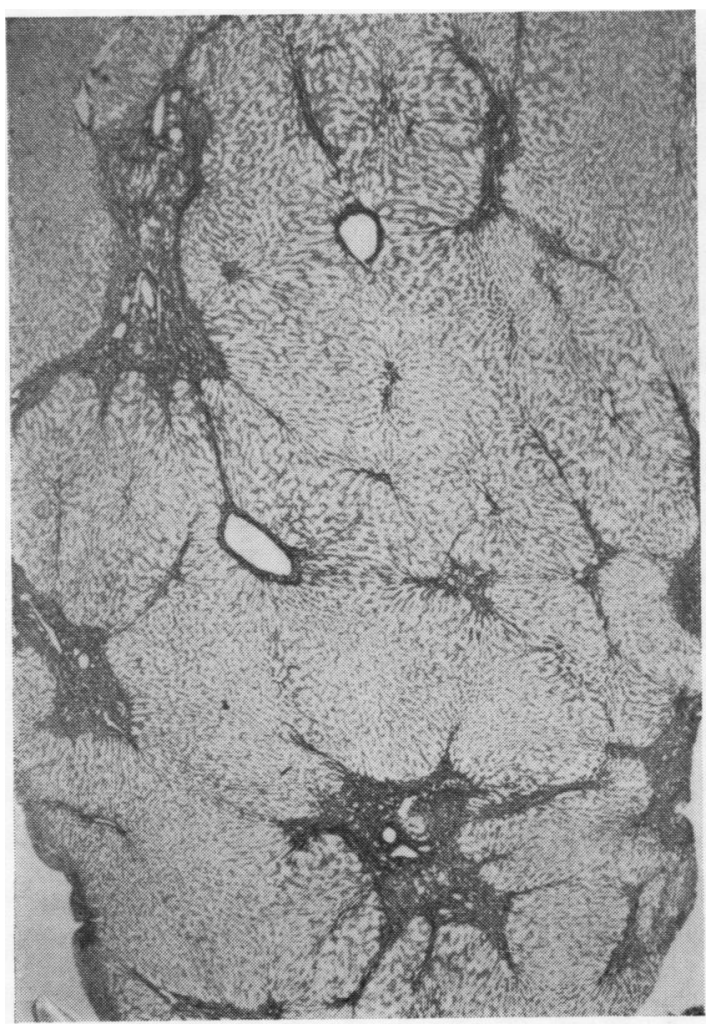

Fig. 1

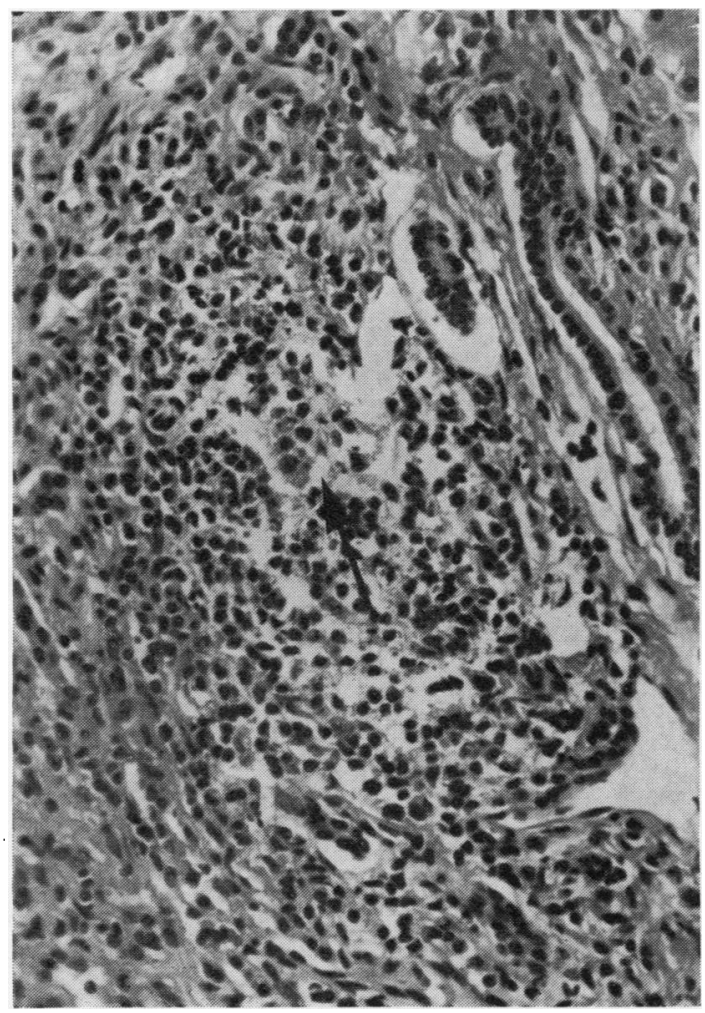

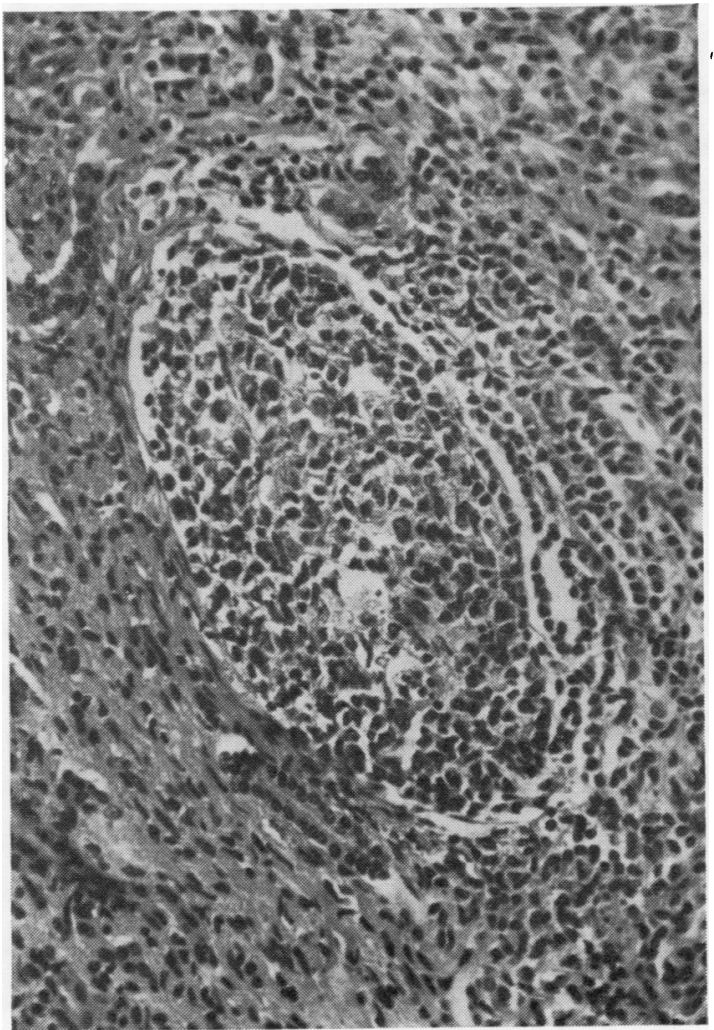

Fig. 2

Fig. 1 Reticulin preparation showing enlarged portal tracts and narrow fibrous strands linking them together (silver impregnation $\times 22$ ).

Fig. 2 Portal tract containing a lymphoid follicle $(H \& E \times 300)$.

Fig. 3 Portal tract with heavy lymphoid infiltration. A small bile duct (arrow) appears to be breaking down $(H \& E \times 300)$. 


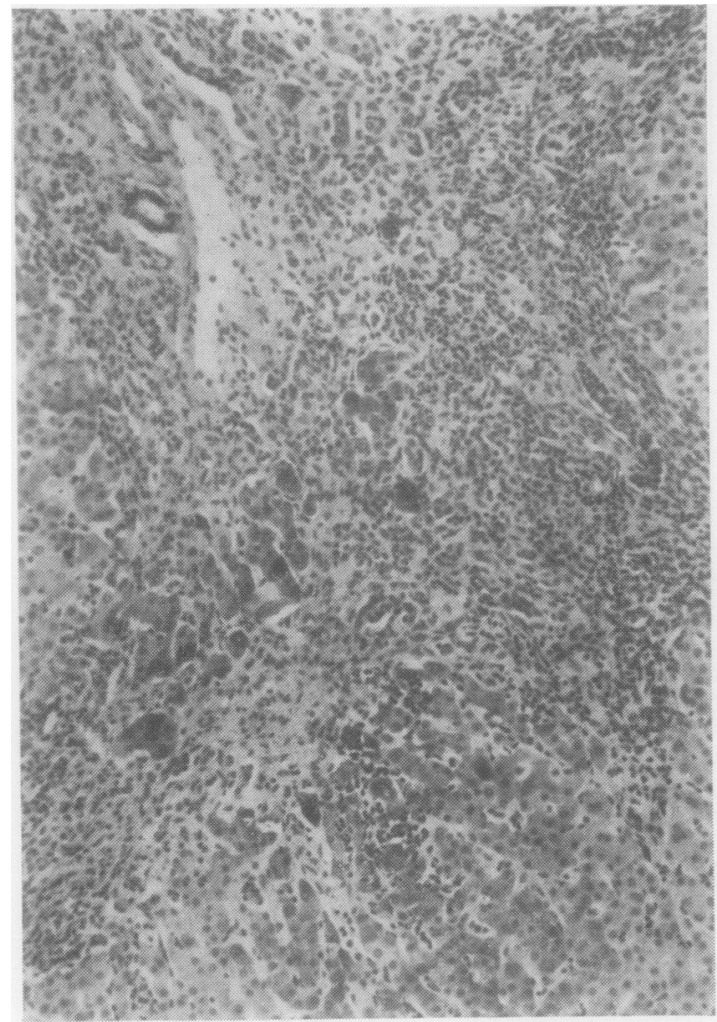

Fig. 4 Dark staining hepatocytes are isolated within an enlarged portal tract (Best's glycogen carmine $\times 120$ ).

Fig. 5 A lower-power electron micrograph shows three adjacent hepatocytes. The cells are well preserved and the field is typical of the sections examined.

Each nucleus is marked with a square and they are numbered 6-8. These numbers correspond to figures 6-8 which show that at higher power these areas contain virus like particles $(\times 11200)$.

Fig. 4

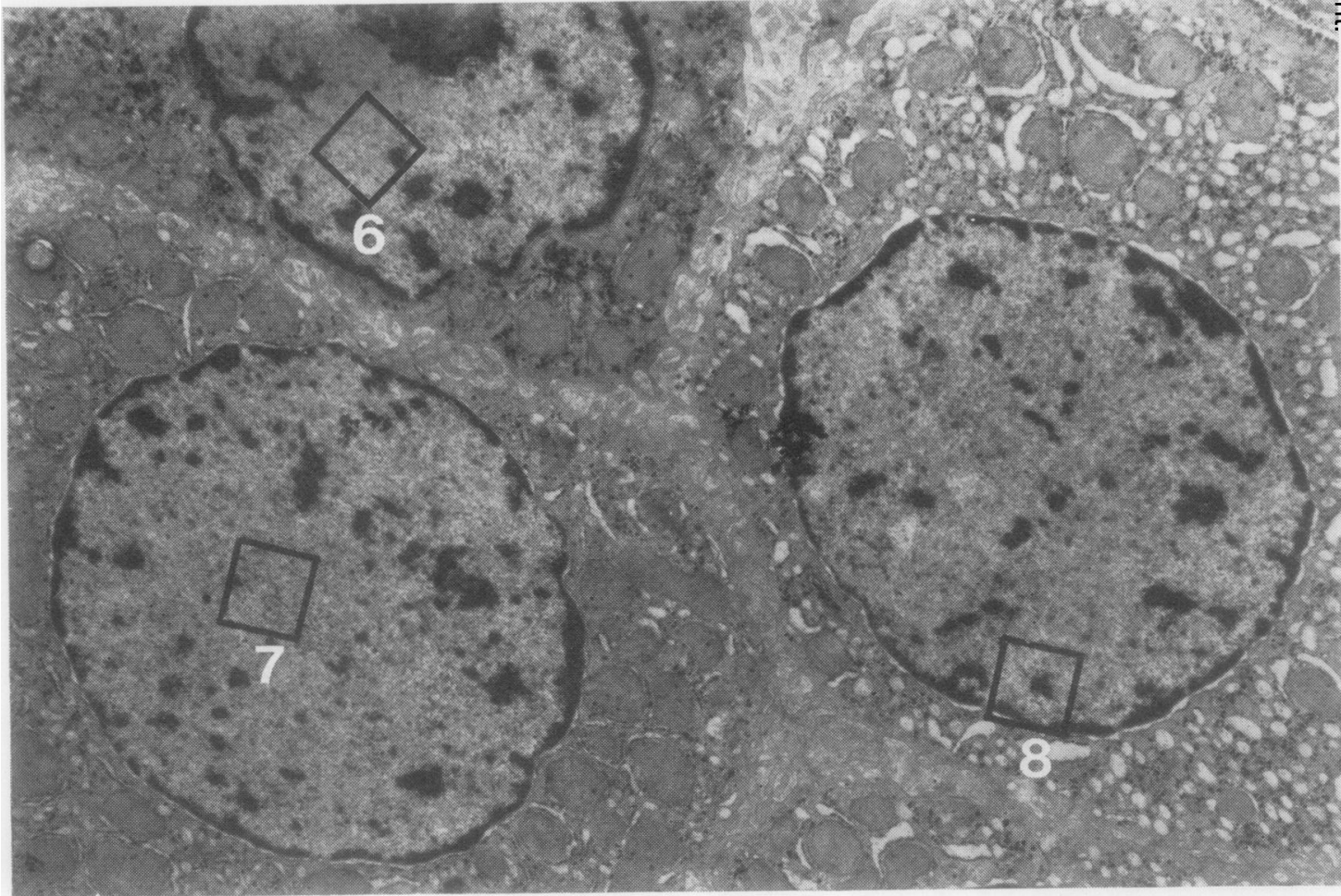




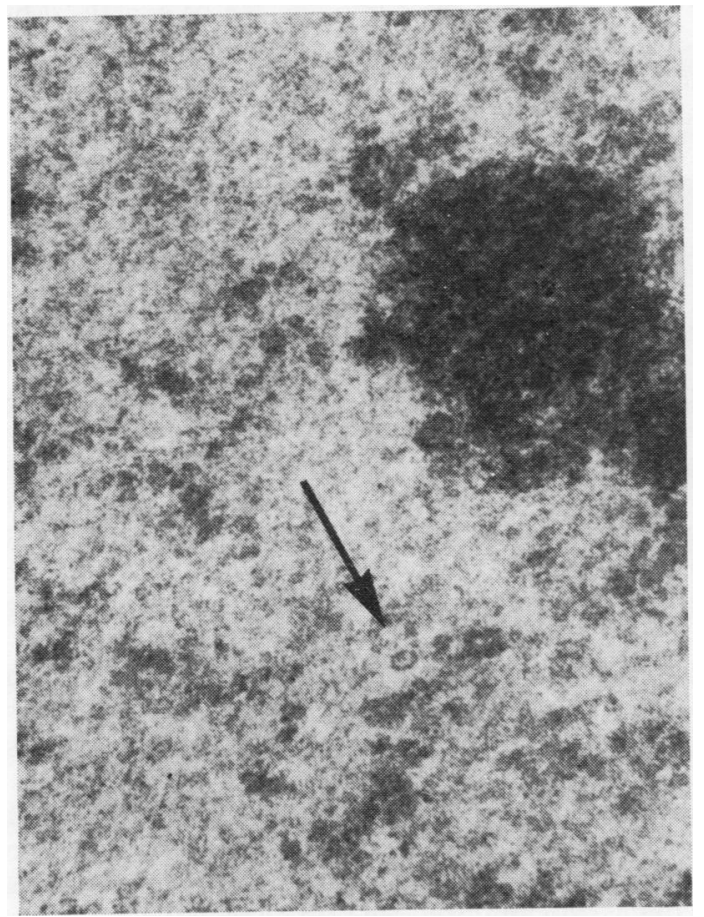

Fig. 6

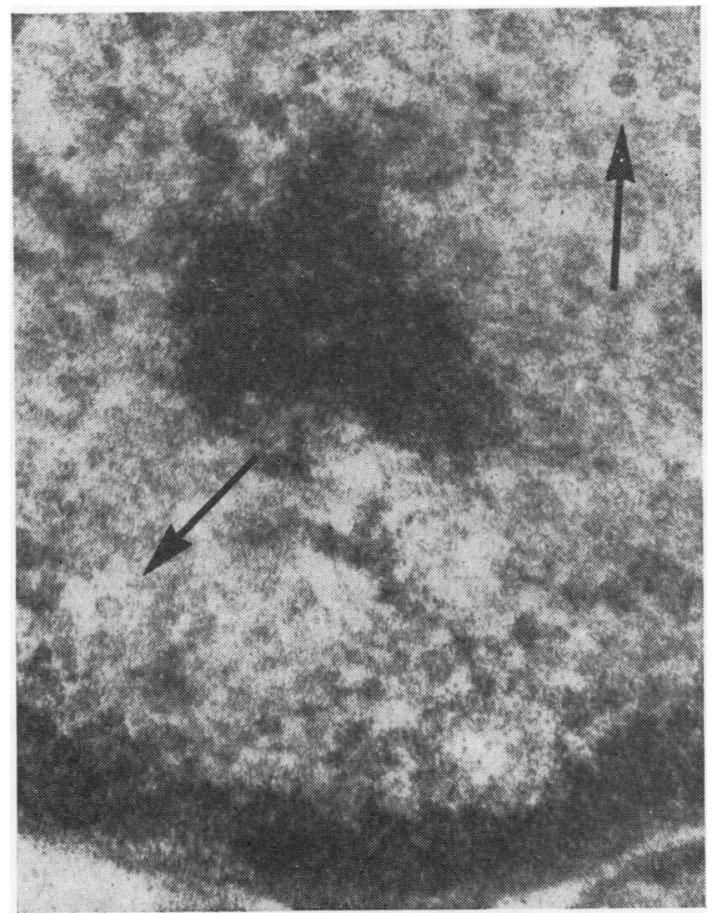

Fig. 8

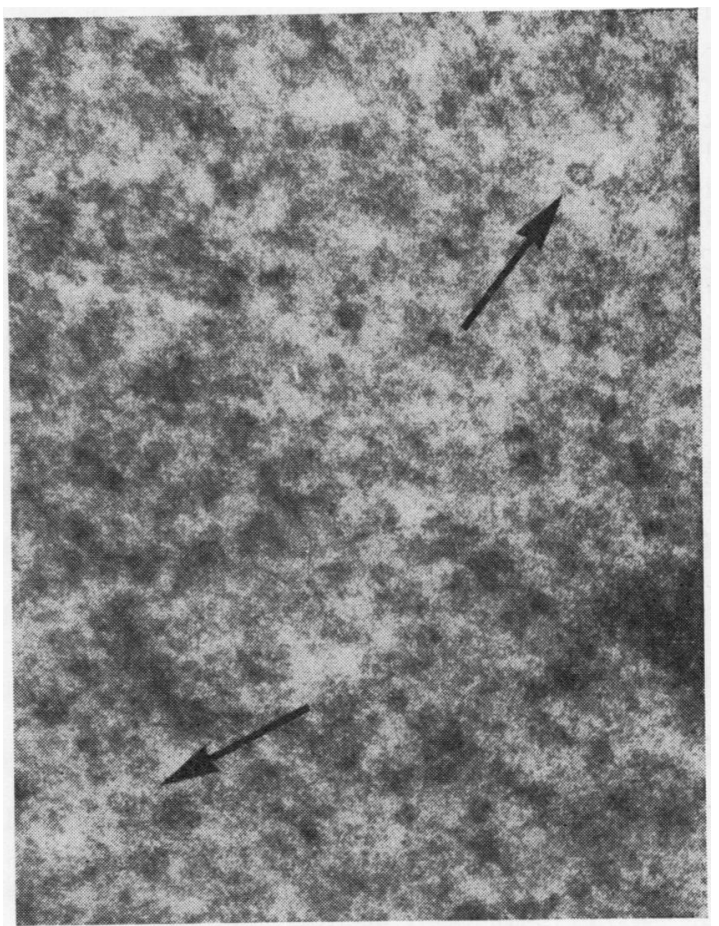

Fig. 7

Fig. 6-8 These micrographs are higher powers of the areas marked in figure 5. In each one a very scanty number of delicate spherical particles are present (arrows), they measure approximately $2000 A$ in diameter, and are identical to those previously described within the nuclei of $\mathrm{Au}-\mathrm{Ag}$ positive subjects $\times 160000$. 
the hepatocytes themselves displayed well preserved substructure of a normal appearance (fig. 5). No obvious inclusions could be seen in either the nuclei or the cytoplasm. However, examination of the hepatocyte nuclei at high magnification revealed that numerous nuclei contained a small number of virus-like particles. These particles had a diameter of $200 \AA$ with a fine limiting membrane giving a ringlike appearance. These appeared identical to those described previously in the nuclei of hepatocytes of $\mathrm{Au}-\mathrm{Ag}$ positive carriers. In most areas careful examination revealed that almost all hepatocyte nuclei could be shown to contain the $200 \AA$ particles. Figures 6, 7, and 8 are high-power micrographs from the areas marked in fig. 5, and, as can be seen, a small number of scattered particles were present in all of these nuclei.

Althbugh a considerable search was made, no nucleus containing numerous particles was ever found.

\section{Discussion}

Recent work has shown that antibody directed against the core of the Dane particle also gives fluorescence in the nuclei of cells known to contain the $200 \AA$ particles (Chisari, McGrath, Dalgard, Kirchstein, Almeida, Edgington, and Barker, 1972). This strengthens the suggestion made previously (Almeida, 1971) that the Dane particle represents the mature virus of serum hepatitis with the intranuclear particle being the internal, nucleic acid containing capsid of the double-shelled structure. However, a paradox exists inasmuch as the intranuclear particle can be found with seeming ease in thin sections of liver tissue from asymptomatic carriers of the Au-Ag but only with difficulty or not at all in individuals who carry the antigen but also have liver involvement. In addition, when the $200 \AA$ particles have been described in the occasional case of acute hepatitis they appear in large numbers in heavily infected nuclei as they do also in the silent carriers. The case that we report here describes intranuclear particles in a chronic aggressive hepatitis and it is of interest that the distribution of particles is different from those previously described. Even with considerable searching through numerous grids from five different tissie blocks, no heavily infected nucleus was found. Rarely could more than five $200 \AA$ particles be seen in any one field. On the other hand, careful scrutiny revealed that almost all hepatocyte nuclei could be shown to contain the particles. In addition, unlike the degenerate hepatocytes showing heavy infection of the nuclei with $20 J \AA$ particles, the hepatocytes in the present case displayed an appearance within the limits of normal.
It is possible that these findings can be explained by 7 postulating that the virus of serum hepatitis is $\vec{F}$ capable of entering into more than one type of 을 interaction with the host cells.

It has been known for many years now that one particular virus is capable of eliciting several different responses depending on host variation (Tyrrell, $\frac{\bar{\sigma}}{\overline{0}}$ 1969). For example, adenovirus type 12 produces a $\frac{\rho}{\nabla}$ lytic response in man, that is, the virus produces $\varnothing$ disease simply by growing in the host cells which क eventually die with release of a new generation of $\overrightarrow{0}$ virus. However, in hamsters, this same virus produces little lytic response but instead acts as an oncogenic $\vec{\omega}$ agent with production of tumours. Similarly, measles $\frac{\Omega}{2}$ virus almost always produces the febrile illness of $\frac{?}{0}$ childhood associated with it but just occasionally it $\stackrel{\sim}{\sim}$ produces instead a degenerative condition of the iv central nervous system known as subacute sclerosing panencephalitis (Brody and Detels, 1970). Frequently, when a virus enters into a relationship with the host other than the simple lytic one it becomes difficult or impossible to recover viable virus and its original presence may only be revealed by the presence of virally coded proteins. If for the moment we accept that the Dane particle represents the viable virus of serum hepatitis and the small forms of the Au-Ag virally coded protein then the following picture emerges.

Asymptomatic carriers of the $\mathrm{Au}-\mathrm{Ag}$ and those suffering from the acute form of serum hepatit $\overrightarrow{5}$ experience a simple lytic infection of the virus with hepatocyte nuclei showing virus replication and variable amounts of Au-Ag appearing in the serum. The difference between the two groups may then rely on individual host immune responses to the virus (Almeida and Waterson, 1969; Dudley, Fox, and Sherlock, 1972). Occasionally, however, either in addition to, or instead of, this lytic relationship, the virus may enter into a more subtle relationship with the host cells. In these instances there could be partial integration of the viral genome into the host cell resulting in very little mature virus production but with variable amounts of $\mathrm{Au}-\mathrm{Ag}$ being expressed. The cells infected in this way would be antigenically altered but would remain viable thus giving rise to a chronic condition. This hypothesis could very simply be checked once a means becomes available for testing specimens of $\mathrm{Au}-\mathrm{Ag}$ for viable virus. If it should be correct, then serum from those experienc- $\underset{\omega}{\widetilde{N}}$ ing a lytic interaction with the virus, ie, carriers and patients with acute hepatitis would be more infectious than that from individuals who were suffering a more prolonged infection with the virus.

It should also be pointed out that the scarcity of intranuclear particles in the present case, together with the fact that these particles are smaller than the 
thickness of most sections for electron microscopy, means that it would be very easy to obtain false negatives when examining liver tissue for them. Also the extremely small ratio of viral material to background nucleoplasm would mean that fluorescent antibody techniques would not be able to detect the presence of particles.

Finally, the fact should be mentioned that it has been found necessary to maintain the child on corticosteroid therapy. There is now considerable evidence that administration of steroids during the acute phase of $\mathrm{Au}-\mathrm{Ag}$ positive hepatitis carries with it a high risk of prolonging the course of the disease and setting up either chronic persistent, or chronic aggressive, hepatitis (Wewalka, 1972). In cases such as these it has been found necessary to continue steroid therapy or the patient relapses into a state of jaundice. The child discussed here would seem to belong in this group but it should be pointed out that he was not initially treated with steroids. Instead he developed measles immediately after his original attack of hepatitis and it is possible that measles virus, known to produce an immunosuppressive effect (Webb and Hall, 1972), acted in a similar manner to that of administered corticosteroids, allowing the virus of serum hepatitis to enter its prolonged course.

We would like to thank Mrs D. Urwin for her excellent technical assistance in every phase of this work.

\section{References}

Almeida, J. D. (1971). Electron microscopic observations and speculations on Australia antigen. Postgrad. med. J., 47, 484487.

Almeida, J. D., Rubenstein, D., and Stott, E. J. (1971). New antigenantibody system in Australia antigen positive hepatitis. Lancet, 2, 1225-1227.

Almeida, J. D., and Waterson, A. P. (1969). Immune complexes in hepatitis. Lancet, 2, 983-986.

Brody, J. A., and Detels, R. (1970). Subacute sclerosing panencephalitis: a zoonosis following aberrant measles. Lancet, 2, 500-501.

Caramia, F., De Bac, C., and Ricci, G. (1972). Virus-like particles within hepatocytes of Australia antigen carriers. Amer. J. Dis. Child., 123, 309-311.

Chisari, F. V., McGrath, P. P., Dalgard, D. W., Kirchstein, R. L., Almeida, J. D., Edington, T. S., and Barker, L. F. (1973). Transmission of viral hepatitis type B to chimpanzees. II. Evidence of intrahepatic replication and hepatitis. (In preparation).

Dane, D.S., Cameron, C. H., and Briggs, M. (1970). Virus-like particles in serum of patients with Australia-antigen-associated hepatitis. Lancet, 1, 695-698.

Dudley, F. J., Fox, R. A., and Sherlock, S. (1972). Cellular immunity and hepatitis-associated. Australia antigen liver disease. Lancet, 1, 723-726.

Huang, S. N. (1971). Hepatitis-associated antigen hepatitis. Amer. J. Path., 64, 483-492.

Nelson, J. M. Barker, L. F., and Danovitch, S. H. (1970). Intranuclear aggregates in the liver of a patient with serum hepatitis. (Letter). Lancet, 2, 773-774.

Nowoslawski, A., Brzosko, W. J., Madaliński, K., and Krawczyński, K. (1970) Cellular localization of Australia antigen in the liver of patients with lymphoproliferative disorders. Lancet, 1, 494 497.

Scotto, J. M., Homberg, J. C., and Caroli, J. (1972). Electron microscopy studies of severe virus hepatitis. Amer. J. Dis. Child., 123, 311-312.

Tyrrell, D. A. J. (1969). In Virus Diseases and the Nervous System: A Symposium, edited by C. W. M. Whit ty, J. T. Hughes, and F. O. MacCallum. Blackwell, Oxford and Edinburgh.

Webb, H. E., and Hall, J. G. (1972). An assessment of the role of the allergic response in the pathogenesis of viral diseases. In Microbial Pathogenicity in Man and Animals, pp. 283-415. Cambridge University Press, London.

Wewalka, F. G. (1972). Protracted and recurrent forms of viral hepatitis. Amer. J. Dis. Child., 123, 283-286. 